quite some time there, and he loved it. I understand that he left his sunlit home to St. Antony's, thereby building a bridge between the two harbors in his life.

An indefatigable wanderer about this earth and a relentless worker, Max Hayward took time to be generous to his friends-encouraging their work, helping it along, fretting over it. There was for them a great deal to learn that was new and fascinating when visiting his unprepossessing quarters, cluttered with books, at St. Antony's. And what a gifted raconteur he was! His wit, humor, and humanity transformed details of life styles and character traits that he had so astutely observed into a spirited chronicle of the Soviet era. He gave much and wanted little for himself.

Fairness and commitment to freedom, decency and scrupulous honesty were Max's qualities.

His legacy consists of translations of books such as Pasternak's Dr. Zhivago, Solzhenitsyn's One Day in the Life of Ivan Denisovich, and the monumental Nadezhda Mandelstam volumes. He also translated many other important works, too numerous to mention. His legacy consists further of gallant and elegant essays, of introductions to literary studies, anthologies, and translations of new literary works, and of scholarly editorial work. He leaves behind no tomes of his own. He preferred midwifery to any gesture of self-aggrandizement. He was thereby somehow very English. Yet it is such a great pity that Max Hayward did not write a book on Pasternak. Perhaps, his clairvoyant eyes and his vigilant curiosity and also, perhaps, the perfect blend in him of pride and modesty prevented Max from becoming a conventional academic achiever. Nor did he ever manage to protect himself sufficiently from taxing demands placed on him by those who needed his expertise. Max Hayward was above all selfless. And so he served Russian literature as teacher, editor, reader of countless manuscripts, adviser to publishing houses, researcher. I do not know how we will go on without him.

Max Hayward died of cancer on March 18, 1979, in Oxford, England. He is survived by his parents and a younger brother. He had no family of his own, but he had many friends. I grieve for Patricia Blake, George Katkov, Edward Kline, Harry Shukman, and for all the others who loved him. Their loss is hard to bear. There never was anyone like Max Hayward.

Vera S. DUnhaM

Queens College, CUNY

\title{
C. BICKFORD O'BRIEN, 1909-1979
}

The small group of historians of Muscovite Russia suffered a great loss when Bickford O'Brien died on January 13,1979. We will miss him not only as a diligent fellow scholar but also as a devoted teacher and adviser as well as a man of integrity and compassion.

Bickford O'Brien studied under Robert Kerner at the University of California, Berkeley, specializing in the history of Russia in the seventeenth century. Immediately after finishing his doctorate in 1942, he served for four years in the United States Air Force. In 1947, he began his teaching career at the University of California, Davis, where he served until his retirement twenty-seven years later. During his years at Davis, the campus changed from a branch of the Berkeley College of Agriculture into a large university and the Department of History grew accordingly. O'Brien played a major role in these developments, teaching a wide variety of courses and serving in many capacities, including seven years as chairman of the department.

All the while he continued his research on Muscovite Russia. In 1952, he published his first book, Russia Under Two Tsars: The Regency of Sophia Alexeevna, which is still the standard monographic study of that short but tumultuous period. 
He next turned his attention to a particularly complex and demanding subject, the history and diplomatic fate of the Ukraine in the mid-seventeenth century. The result, Muscovy and the Ukraine, 1654-1667, was published in 1963. The book is admirable for the thoroughness of the author's research in several languages, his freedom from teleological approaches and nationalistic passion, and the clarity with which he unravels the tangled events with which he deals.

In 1961-62, be began extensive archival research on his last project, a study of the career of the great seventeenth-century diplomat and chancellor, A. L. OrdinNashchokin. Although he did not live to finish a full biography as he had intended, he published several articles on Nashchokin's ideas, his activities as a diplomat, and the diplomatic background against which he worked. These articles, which make extensive use of documents from Soviet archives, display the best qualities of O'Brien's work-clarity, thoroughness, and common sense.

In recent years, he devoted a great deal of time and energy to the campaign to restore Fort Ross, the former Russian settlement on the northern coast of California. He worked with the Fort Ross Interpretative Association and was general editor of Fort Ross: Indians, Russians, Americans, published in 1978.

I respected him as a scholar, but I will remember him most of all as a man. $\mathrm{He}$ was a gracious and helpful colleague, a conscientious and supportive teacher, and a concerned and devoted member of his profession. His integrity was indisputable, his concern for others legendary. He was, in short, one of a rare and disappearing species -a true gentleman. He will be sorely missed.

Robert O. CRUMmey

University of California, Davis 